\title{
FACT AND FICTION IN JOSIP NOVAKOVICH'S APRIL FOOL'S DAY: AN OBITUARY TO A DEAD COUNTRY
}

Nina Sirković, University of Split, nina.sirkovic@fesb.hr

10.31902/fll. 27.2019 .4

UDK 821.163.42.09 Novakovič J.

\begin{abstract}
Even in the world of fiction, it would be unusual for a European country to experience the war at the end of 20th century, fall apart and disappear. This exactly happens in Josip Novakovich's novel April Fool's Day. It is a Bildungsroman about life, death and the afterlife of Ivan Dolinar, a Croatian citizen of Yugoslavia, whose life undergoes unbelievable twists and changes as the social and political situation in the country deteriorates until it falls apart and a new homeland, Republic of Croatia, is formed. On the basis of historical facts, the author develops a story about a fictional hero, who himself is a personified disintegrated country: the instability of the main character shows the instability of the state. During his life, driven by the fate and historical forces, Ivan becomes a political prisoner, a murderer, a rapist, an adulterer, a thief and finally, a ghost. Only when considered dead, he can be a master of his life. Ivan Dolinar finds harmony in his afterlife: as a ghost he is liberated from all the living inherences, in his death he feels free, important and unique, what he did not succeed during his living days. The novel is simultaneously a war and a ghost story with strong satirical impulse and black humour targeted towards human vanity and imperfection, lust, hatred and absurdity of war in general.

The aim of this paper is to explore the interconnection between the fact and fiction in the novel, which intended to be, according to Novakovich, "an obituary to Yugoslavia in a personal form". This fictional story that describes details about life and death of Ivan Dolinar is a story of a war-torn country which can only live in the form of a ghost until it completely disappears from our minds.
\end{abstract}

Key words: Josip Novakovich, Bildungsroman, war story, ghost story, satire, fact, fiction.

\section{Introduction}

Josip Novakovich is merely a well-known and awarded author of short story and essay collections and April Fool's Day represents his first novel. This Croatian-American writer who left his homeland in 1977 at the age of 20 as a transfer medicine student, came to Yale to study religion and philosophy and finally pursued his career in writing in English as a second language. The themes in his short stories and essays cover a vast rage of interest, including social and cultural issues 
dealing with problems of immigration, exile and identity in diaspora, as well as influence of inevitable changes on the political, social and cultural level at home. Through different perceptions of a country in a post-war period in the process of restoration, combined with recollections from the past, the question of identity reconstruction is raised. National heritage and tradition point out the absurdity of war in new socially constructed spaces.

In his writing, Novakovich tries and succeeds to avoid any politics-oriented writing, because, in his opinion, any writing with a political mission can only damage the quality of text. (Moschin) Hence, his protagonists are of different ethnicities, regardless of whether they are Croats, Serbs or Muslims, they all suffer in the same way because the war is a universal evil.

Novakovich's heroes are people of different nationalities, sometimes of a different gender, sharing similar fate and proving that the war is a horrific experience for each side and that the only ones who benefit from it are criminals, whereas all the others are victims. (Novakovich 2010, 8-9) They often find themselves in absurd situations where their enemy becomes a friend and a friend turns to be an enemy. Characters are driven by their fate, such as in "A Purple Story" ${ }^{4}$, which is set in a hospital where an ethic Serb who was waiting for a heart transplant, survived by accident because the heart which was meant to be for him, was transplanted to a Croatian army general, who died right afterwards, since the transplanted heart had a failure. "Hail" is a story set in Bosnia during the war. Haris, the Buddhist and pacifist, forcefully enlisted in the Bosnian army was accused of treason after his company had attacked another Bosnian company instead of Serbian by mistake. Their comrades tied him to a tree and were about to kill him, when suddenly Serbs appeared and, having seen him tied up, thought that Haris was one of theirs. They set him free, but now they forced Haris to kill his comrades and get revenged. These unexpected twists where yesterday's comrades become worst enemies and enemies seem to be friends show the whole absurdity of war, where there is no trust and honour, just the raw impulse for survival. Mira, the main protagonist of the short story "Ribs", gets into sexual relationship with a director of a recruitment centre to prevent her son to go to the war after her husband, a member of Croatian army had disappeared in the war. At the same time, the director happened to be involved in the death of her husband, who was killed by his comrades because he

\footnotetext{
${ }^{4}$ This and the following short stories mentioned in this paragraph are from Novakovich,'s short story collection Infidelities: Stories of War and Lust. 2005.
} 
refused to shoot Muslim civilians in Bosnia. The main character of a story called "Snow Powder" is a primary school boy who, angry with his parents and hating school, helps enemies Serbs to bomb and destroy his village, just hoping that they would put the school down as well. "Spleen" is a story of an immigrant girl, described in the first person, who is unable to continue normal life in America, after being raped in the war because she sees her rapist in every man who approaches her. The diversity of characters described in these short stories and their destinies are testimonies about the absurdity of war and suffering that all parties in the war are exposed to.

April Fool's Day is a novel that mainly deals with the war. War is the topic that the author has been occupied with and, according to his own words, as most of writings about war was journalism, he turned to fiction, feeling that, trying to understand the terror that people suffered during the war, he would better express it through individual stories. In the afterword of the novel, Novakovich explains what inspired him to write such novel. The first impulse for writing came to him after having read famous Tolstoy's novella The Death of Ivan Ilych, which deals with spiritual reflections and questions of meaning of life and living a life without meaning. $(2010,8)$ Lying on his deathbed, Ivan Ilych confronts the death. He meditates about his life and past actions and realizes that a bad and empty life brings death of the soul.

Inspired by Tolstoy on one side, and, having closest experience with dying of his father when he was only 12 on the other, Novakovich wanted to write a "a good death story" with "particularly the moment of dying there." (12) His father's death was torturing him constantly, so it was easy for him to "slip into telling a ghost story." (13) For a long time this event was too painful to face and finally he decided to write satirical stories about dying, to deal with a painful issue in a comic and humorous way. He wanted to leave pain and fear of death behind and chose, in his own words, comedy as a completely different approach. In April Fool's Day Ivan Dolinar experiences death in every moment of his being and the reader is aware of his single thought and feeling at these moments.

It seems that the author's father, whose name was also Josip, had left a great influence on him. In his essay "Dead Fathers Society". (201) Novakovich goes to the past and explores relationship with his father and finds many things in common with his friends who have also lost their fathers. The father loved music, played several instruments and used to tell fantastic stories to his children, so he probably influenced Novakovich's interest in storytelling. He confirms, April 
Fool's Day comes out of his father's death and since he was a child when he lost his father, he wanted to give him a role in his life, so that "his absence is a form of ghostly presence." (23)

Since April Fool's Day follows the development of the character of Ivan Dolinar from his birth to his very death, even his afterlife, the novel can be regarded as a Bildungsroman. One of interpretations of the Bildungsroman is that it is a bond between (auto)biography and picaresque novel. (Buckley 1984, 24) In the biography, which has a similar narrative form as the Bildungsroman, the story is focused on a single person and increasing psychological realism. Nevertheless, the distinctive abstraction of reality makes two genres differ: in the autobiography the author, narrator and main hero are the same, whereas in the novel only the author is real: the narrator and the main character are fictional. In the Bildungsroman, the fact mingles with fiction. (23) Biography tends to be objective and factual, whereas in the novel the author admits to telling a fictional story. (Núbel 2000, 471)

Since the main protagonist in the Bildungsroman goes on a journey in order to experience and learn about the life and world, he/she is similar to the picaro, who also drifts from place to place, seeking for the adventure. Unlike picaro, who remains the same and does not learn from the world, the hero/ine of the Bildungsroman undergoes a kind of development, his/her conscience, memory and attitudes change and mature towards the end of the novel and in the end the hero/ine has found his/her place in the word, accepted certain social rules and has a spiritual peace which is paid by conscious conformism.

April Fool's Day follows the development of Ivan Dolinar, a Croat from Nizograd (an imaginary town in Slavonia) from his birth, over his childhood, student days, mature years until his death and even his afterlife. Dolinar had a rather turbulent life, left his hometown to study in Novi Sad in Serbia and, as a victim of misunderstanding, ended in the political prison on Naked Island on the Croatian coast where he spent next three years. After that, Ivan continued his study in Zagreb and returned to Nizograd again, but got enlisted in the Yugoslav army where he was still when the war in Croatia started. Captured by the Croats, ended in a camp in Bosnia and succeeded to escape and finally returned home, where he spent the rest of his life. Ivan's aspirations and desires were always in conflict with his achievements, as well as with his social surroundings and his life struggle was over only when he was considered dead. 
During his life, Ivan, like a picaro, went from one adventure to another, more driven by the fate than by his own will. On his journeys he constantly met obstacles and got into conflicts with the social community and somehow never found the right way to be a member of it. As the author himself said, the character of Ivan Dolinar is personified Yugoslavia, a country which lasted less than the main character's life. Novakovich says: "This country was a strange one, and I play with the sensation of paranoia, the power obsession and the sense of uniqueness that plagued the country." $(2010,12)$

The relatively short but rather unhappy life of Ivan Dolinar and the story of his death is the representation of the life and death of a country which no longer exists and can haunt us from the past only like a ghost, like Dolinar's ghost character haunts the citizens of his hometown.

Novakovich believes that imagination can compete with journalism, where he gives huge advantage to fiction because of the subjectivity experience: one can be expressive about other people's thoughts and feelings, not trying to convey them literally, but to transform them through individual experience. (12)

\section{Fiction and non-fiction}

\section{Growing up years}

April Fool's Day is a novel which deals with historical facts, but at the same time it is a personal testimony about life, love, lust, religion and experience of death. When writing a novel, the author combines historical facts with fiction: through the voices of history an individual story is told, the story which in turn, invokes phenomena belonging to specific space and time. (Lodge 15) This is also to be found in Novakovich's novel.

The hero of the novel was born on $1^{\text {st }}$ April 1948, and, since his parents did not want the April Fool's Day to be the birthday of their son, fearing he might go through life like an April Fool's joke, they registered him on $2^{\text {nd }}$ April in the Birth Registry in Croatian town Nizograd. They also gave him the most common name in the region, Ivan (John). The insignificant, simple name and the birthday on the April Fool's Day seem to have marked the young boy from the beginning of his life. Several months after Ivan was born, his father died of delirium tremens and few months afterwards, his brother Bruno was born. Ivan fell in love with power since he learned how to crawl. He screamed for breastfeeding even when he was not hungry and always wanted to be in the centre of attention. When he got a competition, he used to torture his younger brother, pull his nose and 
ears, lock him in the dark, and behave stupidly, so his mother often punished him for beating Bruno. She even thought that Ivan was slightly retarded and sent him to school a year later. Since he was a year older than his classmates, Ivan wanted to be the strongest and bravest, always tried to impress his colleagues with stupid ideas, like trying to lie down on the tracks under a passing train but in the end, he always proved to be even more ridiculous.

1950s and 1960s were decades of strong socialist propaganda and glorification of the president Tito and his Party. Being raised in such environment, Ivan felt love and adoration towards state apparatus. Two events from his childhood show that he really misunderstood the time he was living in and on both occasions he was beaten by his mom. It seems that in that period of political hysteria he had none, not even a family member, who could regard him as a vulnerable human being. For the Day of the Republic, children used to make national paper flags for school decorations. Being lazy on one side, and wanted to show their love for the Republic on the other, Ivan and his friend Peter found some decorative paper flags hanging from the electric wires on the street and took as more as they could, aiming to bring them to the teacher to show their appreciation of the Party. When they came to school, the teacher found out that someone had stolen flag ropes from the centre of the town. She accused two boys of conspiring against the country, brotherhood and unity. The boys were too scared to try to explain that they had gathered flags to celebrate Communism they were accused of subverting.

It was the very day when Soviets occupied Budapest and Tito held a speech which echoed from the loudspeakers through streets. He said, they had defeated the Germans and would defeat Soviets as well if they came because Yugoslavia had the best trained and most disciplined army in Europe. (2010, 11-12)

The other misunderstanding in which Ivan also got beaten was when he wrote a letter to show his admiration for the president Tito. ${ }^{5}$ Tito's birthday was the national holiday called "Day of Youth" and it was celebrated on $25^{\text {th }}$ May. ${ }^{6}$ Ivan was fascinated with Tito and stories about his heroic actions from the war and decided to write the best letter of all students in the class. His family belonged to Calvinist

\footnotetext{
5 "The admiration for the president was institutionalized." (13)

${ }^{6}$ Novakovich makes fun of the way Tito spoke:"When Tito delivered a speech, though nobody could tell for sure in which language: whether Croatian with a Russian accent, or Slovenian with Serbian vocabulary, or Ukrainian with SerboCroatian vocabulary. No (Slavic) national group could feel neglected." (13)
} 
church and he remembered Sunday praying where the main point was to praise God as much as possible. He wrote a letter in the form of a prayer:

Our Most High president!

Hallowed be thy name, thy will be done abroad as it is done at home, give us our daily bread and soccer balls of leather.

Our most high, omnipotent, omnipresent, and omniscient President, we love you, beyond the power of reason. No words are good enough to express how omniwonderful you are. We are honoured that as worms we are allowed to crawl on the dusty road of socialism. [...]

Thanks a lot. Glory to thee, glory that beats all human and divine reason.

Death to fascism and freedom to the people!

Your warmly comrade,

Ivan Dolinar. (14-15)

The letter was considered as cynical provocation which would never be expected from a child and his letter was torn in front of the classroom. Ivan was punished again, but again, nobody explained him what his mistake was. He wanted to worship the President as the God is worshipped in the church - he appeared to be a divine creature to him. All around him there were pictures of the President, he was praised and cited and there was a worship cult about him. And when Ivan tried to say that Tito was his God, he was severely punished.

Ivan's misunderstanding of his environment and a lack of political intelligence continued during his university days. He went to Novi Sad to study medicine and lived in the dormitory which resembled "little" Yugoslavia, his roommates were a Serb and a Muslim, also medicine students. Ivan was a successful student, but an innocent event drove him and his colleague Aldo to prison for political prisoners on Naked Island. Aldo brought Ivan to his flat where he had two rifles, and, angry with President Tito, because he could not get Tito's Scholarship, suggested to assassinate him, like Kennedy was killed in Dallas. Somehow they were captured by the police and, although they did not have any guns with them, and Ivan apologized he did not know how to load the gun, both were arrested, and without a trial or judge (it was a case of "state security") sentenced to four years of labour on Naked Island, a prison-island on the Adriatic coast.

During his stay on the island, Ivan was humiliated in every possible way, he grew thin and nervous and suffered headaches. One day president Tito visited the island with his friend Indira Ghandi. Although historic documents claim that Tito never visited this island, it 
is well known that Gandhi was a close friend to him for years because Yugoslavia was one of founders of the Nonaligned movement together with India. The encounter of Ivan with two statesmen is described in highly satiric way, in all this misery and prison terror Indira Gandhi gave him a fan as a gift, and Tito a cigar and taught him how to smoke it.

Ivan was released from the prison the time of Croatian Spring a movement started by some Croatian politicians and intellectuals in order to separate from the state and form an independent republic. The number of political imprisonment raised drastically at that time. As he had a political record, Ivan was not allowed to continue his medicine study, but was admitted to philosophy department in Zagreb, where, as the author ironically writes "a bad political record did not mean anything detrimental - on the contrary, it was a matter of prestige to have been imprisoned." (58) Although considered as a political ex-prisoner, Ivan had little sympathy for the nationalists and was not interested in politics at all. He liked philosophy and became a vegetarian. After finishing university, he could not get a job as a philosophy teacher and returned home to Nizograd where he taught basic sciences.

In his spare time, Ivan worked and earned money on translations. He translated books on marriage and theology for several Protestant churches. His German was miserable, but nevertheless he wrote translations in the way that he improvised, he wrote what he regarded it was acceptable for the church: sanctity of marriage and other predictable facts. On one side he wrote completely wrong translations, and on the other, he was very dedicated to his work: he looked over every word in the dictionary, laboured over every sentence, put a lot of effort to make his "translations" look holistically. His "translations" echoed his whole life: a lot of effort for a completely wrong result.

Ivan still wanted to be distinguished from the others, and accepting that he could not be powerful, he decided to be unique. Somehow, he only did not know how to manage that, what to do to distinguish himself from the others.

In Yugoslav socialist totalitarian regime, the love and worship for president Tito was deeply rooted in the whole nation, and, when he died, the whole country was crying over him. Ivan also cried, although he himself wondered why, because the president caused him so much pain and sorrow. He was raised to worship the authority and to be afraid of it:

Ivan should have felt joyful, but he was afraid to feel joy at the end of the "cult of personality" era, as though Tito had supernatural 
powers and his bugging system could asses minds, register thoughts, report them to the police, and, as though Tito himself would arrange for his tortures here and beyond. (83)

\section{War story}

After Tito's death, the situation in Yugoslavia became turbulent. Ivan felt threatened, he was a Croat, although he did not feel like Croatian. He voted for the Croatian Democratic Union because it promised strong self-defence, but did not join the party, considering it was assertion of individuality. Just as Croatia was about to organize its own police forces, Ivan was called to join the Yugoslav army. The absurdity began again, because just as Croatia announced the War for Liberation, Ivan, as a soldier of Yugoslav Federal Army was sent to Croatia to fight the Croats. In such unbearable situation, Ivan turned to religion. He used to read the New Testament, which he had stolen from a deserted village near Vukovar. He felt it was not his war, what also shows the episode with an unknown man whom he found in one of the houses. After he captured a man in the village, his captain ordered him to shoot the man. Ivan felt like a looser:

He tried to conceal the trembling of his hand [...] He was scared in front of groups. In that sense, he and the man had more in common than any of the soldiers; they both faced the group. The man could do nothing about it; for him it was fate. Ivan, on the other hand, could pull the trigger, or not. Objectively, not to pull the trigger would be the right choice. But in front of the deranged group, it would be the wrong choice. No matter what he did (or did not do), it would be wrong and would work against him. (117)

In the end, he pulled the trigger three times and it seemed to him that he did not feel anything. A little bit later, his rage will come to the surface and he will, defending a girl being raped by the same captain, smash his face with a rifle until it becomes unrecognizable. It proved that the raped girl was Selma, his colleague from Novi Sad. He saved her by putting her on a bus with Croat women and children. Later they will meet again and get married.

Not knowing what exactly he was doing in the army and why he was fighting at all, Ivan managed to escape during a Croat attack and, although wounded, found a deserted village where he managed to survive until he was caught by the Croat soldiers. They did not believe him since he could not prove he was Croat and sent him to a camp combined of Croats and Muslim forces near Sarajevo. There he spent several months until they were attacked by Serbs and in the end, Ivan became a prisoner of the Yugoslav Army he had recently served. 
He was tortured by Chetniks as a POW. One day on the way to a detention camp, they were attacked by Muslims and Croats and, as he was wounded, he was exchanged from a prisoner camp in swapping of soldiers.

The unbelievable war path of Ivan Dolinar and his miraculous survival shows the absurdity of war in which a human individual is sometimes left to fate - Ivan was driven from one army to another, captured and tortured by both sides and used as a weapon for completely opposite, but at the same time, the similar interests.

\section{Ghost story}

After the war Ivan got married to Selma and when they got a baby girl, his character showed first emotions. When he held Tanya for the first time, he was overjoyed. He thought, he would have a friend for life. (124) Very soon his, at the beginning happy marriage was over, he was displaced by the infant. The child occupied her mother's full attention and Ivan was again neglected. Somehow, at the same time his nightmares started, he felt worse and worse and spent days doing medical examinations. The doctor thought at first that his illness was psychological and gave him placebos, but as he still felt bad, he continued with medical exams. The results always showed some disorder and with the time, Ivan developed hypochondria and was not able to have a simple meal without at least five pills for different deceases.

After the war, he was unable to find a job as a teacher. The economy in the whole country was almost nonexistent. People thought that, after liberating from socialist regime, the country would flourish, but it did not happen. Slavonian Croats blamed Herzegovina Croatians for taking all the better jobs. The national factories and companies were privatized and the economy stopped functioning. People almost felt nostalgic for the old country. Ivan also worked at the factory, but found no friends or satisfaction at his working place. His life was miserable as before. The only thing that made him temporarily happy, was when he found a mistress, the police chief's wife. He found their relationship as "the triumph of humanity over the nationalist regime." (150) After president Tudjman died, Ivan did not feel that the country had lost the father of the nation. He wondered whether the country would become prosperous, the sanctions would be lifted and tourist would start coming to the coast. He went to his mistress to celebrate, but was kicked naked on the street by her husband. Ivan felt all the emotions that a human could feel in such embarrassing situation: 
panic, shame, humiliation, pain. From then on, he stated to suffer from chronic shame. His health deteriorated and his heart troubles started.

Ivan felt it made no difference if he was dead or alive. In his life he had not done anything significant or important to be remembered. Death horrified him, and on the other hand, he was worried that he had lived in vain. Coping with all these contradictory thoughts, one day he suddenly felt something like a stroke and stayed paralyzed. His eyes were open, he could not move or feel his heart beating. He was pronounced dead of unidentified causes because the local doctor was more interested in his wife than in examining him. Ivan was buried at the local graveyard. All the time of funeral preparations and during the funeral, Ivan was aware of everything what was happening around him. He could not move, but he could breathe, his heart and brain were working - he felt alive. No one noticed anything, because it seemed that no one was interesting in him. Finally he felt free:

He now had leisure and no distractions, no worries about how to make ends meet (his ends would meet soon enough). Now he could think honestly. He did not to worry about his thoughts were presentable, clever. No need to worry about politics anymore. What a relief! His death would be his own and nobody else's - a private event outside the scope of socializing and nationalizing. In his coffin there would be no spying, intimidation, balkanization, propaganda, ideology, war taxation - nobody could disturb him. He was free to think about what really mattered - death, eternal life, soul God. (171)

After he was buried, Ivan succeeded to get out of his grave, thanks again to human faults: he could breathe because his coffin was damaged when his wife was making love with the doctor on the same table where the coffin was, and also, there was a rumour that Ivan was buried with a valuable watch, so a thief dug out his coffin trying to steal it.

In his death, Ivan was a free man - he was registered as dead and even at the police station, the same police chief who threw Ivan naked on the street, sent him out to go where he belonged, to the graveyard. Ivan wondered through the streets of his hometown as a ghost, had no worries about what was happening, whether the football supporters of Hajduk and Dinamo would start a street fight, or whether Croatia would split into five tiny countries, all these problems were behind him. He felt love for his daughter Tanya and used to visit her at home when his wife was out. He was happy and relaxed and finally had some quality time with Tanya. She was the only person who accepted him as being alive and was not terrified by him. On the attic he found a fan given to him by Indira Ghandi and he passed it to her. Ivan 
returned to his old habits from the past, like reading Tolstoy's War and Peace.

During his life, Ivan was unimportant, insignificant and his behaviour and actions were often misunderstood. He went through his life as an unhappy and indifferent man, emotionally detached from both his family and community. Oppressed by the communist and socialist society, later also by the new democratic regime, Ivan could find his happiness only when he was completely free, in this case, by the sequence of absurd events and situations, when he was legally pronounced dead.

It seems that after his death Ivan Dolinar became finally famous and remembered for something, even not on his own merit after the story of his ghost wandering around, more and more people started to visit his grave, not only from Nizograd, but also from far away and it seems that he even got cult followers.

\section{Conclusion}

The strange story about Ivan Dolinar's life and death remains ambiguous until the end of the novel. At the very end, even the main character was not sure if he was dead or alive. After one of his walks, on his way to the graveyard Ivan felt tired to dig his grave to lay in the coffin. He preferred silence of the graveyard to any happiness in the turbulent city. At one moment he asked himself:

But what if instead of finding an empty coffin he found his own body there, already in a somewhat advanced stage of decay? That thought, though he at first deemed it to be merely a fantasy, gave him a chill. What if indeed he were solidly dead, and all this roaming around was just a spasm of his imagination? (224)

The author plays with the reader, firstly by creating the story of Ivan Dolinar's afterlife and then, by his own questioning of his existence in his death - is he alive or is he really a ghost? This satirical dark comedy reminds us on Hašek's The Good Soldier Švejk because of strong anti-war message and absurd situations the main character falls into throughout the novel. The both characters, Švejk and Ivan show passive resistance, they are driven into most absurd and comic adventures without their own will. They both became prisoners, Švejk because of some innocent political remarks and Ivan completely by a mistake. Both of them also become POW of their own troops, after being mistaken for enemies. Nevertheless, there is a great difference between two of them: although they are both unlucky and oppressed by the ruling regime, Švejk is a simple minded, uneducated person, whereas Ivan is an intellectual who is interested in medicine, religion, 
philosophy. Through strong irony Hašek and Novakovich show same social and national stereotypes, human intolerance, ignorance and horror that the war brings to all sides involved.

The character of Marko Kovacevic, a citizen of Nizograd is mentioned not only in April Fool's Day, but also in some other stories written by Josip Novakovich. ${ }^{7}$ He was a sculptor educated at the Moscow Art Academy and a communist even before WWII, owner of several war medals. After the war he became so frustrated and disappointed with the regime he was fighting for and bravely excommunicated himself from the Party and threw his membership card into the garbage. After that, of course, he could not find a job and ended as a tombstone maker and an art teacher at the primary school. He became a bitter and disillusioned man. When the tension between Croats and Serbs in Nizograd culminated, he gave a speech in which he called the political leaders hypocrites. He told the gathered people that the God had created all of them equal, regardless of their nationality. God did not care if they were Croats or Serbs. Nobody would expect of Marko, as an atheist and ex-communist, to turn to religion. When he died, everybody wanted to claim he had been one of them, but Kovacevic was buried according to his will: without a star, without a cross or any other emblems or customs that would show any national or religious origin or belonging.

Marko Kovacevic is a symbol of lost illusions and ideals. He is a man who is disappointed in all political regimes, leaders and parties, but still believes in human equality and equal human rights. Ivan Dolinar was not a political member of any party and he was a Calvinist, but he shares same philosophy with Marko - both characters do not belong to any particular social or political group and act as outsiders, bearing deep inside a sense of humanity and justice.

The character of Ivan Dolinar is a personification of the decay of Yugoslavia. It should have been a country of brotherhood and unity of different peoples, a country of prosperity and equality, but it turned into a paranoid, propagandist self-centered organism which in the end, became self-terminated. On the basis of factual events, Novakovich tells a fictional story of the collapse of a myth, a story of a war-torn country which can only live in the form of a ghost until it completely disappears from our minds.

\footnotetext{
${ }^{7}$ See the short story "Rust“ (Novakovich 1995)
} 


\section{References:}

Buckley, Jerome Hamilton, Season of youth: Bildungsroman from Dickens to Golding, Michigan, Harvard University Press, 1984.

Lodge, David, The Modes of Modern Writing. Methaphor, Metonimy and the Typology of modern Literature, London, Edward Arnold, 1998.

Novakovich, Josip, Shopping for a Better Country, Westland, Dzanc Book, 2012.

April Fool's Day, New York, Harper Perrenial, 2010.

---------Infidelities: Stories of War and Lust. New York, Harper Perennial, 2005.

Yolk, Saint Paul, Graywolf Press, 1995.

Moschin, Sara, Interview with Josip Novakovich, in II Tolomeo, vol. 18, 2006.

Nübel, Birgit, Autobiografski i komunikacijski mediji oko 1800. godine, in R:E:Č. Časopis za književnost, kulturu $i$ društvena pitanja, 60.5, 2000.

\section{STVARNOST I FIKCIJA U ROMANU PRVI APRILA JOSIPA NOVAKOVICHA: NEKROLOG POKOJNOJ DRŽAVI}

Gotovo je nevjerojatno zamisliti da krajem 20. stoljeća neka europska država zarati, raspadne se i nestane. To se upravo događa u Novakovichevom romanu Prvi aprila, Bildungsromanu o životu, smrti i zagrobnom životu Ivana Dolinara, hrvatskog državljanina rođenog šezdesetih godina prošlog stoljeća u Jugoslaviji. Njegov život doživljava nevjerojatne prevrate usporedno sa društvenim i političkim promjenama u državi koja se na kraju raspada i iz čijeg dijela nastaje nova, Republika Hrvatska. Na osnovu povjesnih činjenica autor razvija priču o fikcionalnom junaku koji predstavlja zemlju u raspadu: nestabilnost Ivana Dolinara zapravo je nestabilnost bivše države. Tijekom života, vođen sudbinom i povjesnim silama, Ivan postaje zatvorenik, ubojica, silovatelj, preljubnik, lopov, a na kraju i duh. Tek kad je proglašen mrtvim postaje gospodar svoga života i nalazi mir: kao duh, on je oslobođen svih prepreka i utjecaja, osjeća se važno i posebno, što mu za života nije polazilo za rukom. Roman je istovremeno priča o duhu i priča o ratu ispričana sa puno satire i crnog humora, koji razotkrivaju ljudsku sujetu, nesavršenost, žudnju, mržnju, kao i sveukupnu apsurdnost rata.

Cilj rada je istražiti međusobne veze između činjenica i fikcije u romanu, koji je, po autorovim riječima „nekrolog Jugoslaviji u osobnom 
obliku". Roman koji govori o fikcionalnom životu Ivana Dolinara zapravo je priča o ratom razorenoj zemlji koja još jedino može živjeti u obliku duha, dok potpuno ne nestane iz našeg sjećanja.

Ključne riječi: Josip Novakovich, Bildungsroman, ratna priča, pričao o duhovima, satira, stvarnost, fikcija. 